\title{
New Methods for the Implementation of Joint Investment and Innovation Projects in Developed and Developing Countries: Experience of the Republic of Kazakhstan and the Russian Federation
}

\author{
Saule Abaibekovna Rakhimova ${ }^{+*}$ and Lyudmila Petrovna Goncharenko ${ }^{\dagger}$
}

\begin{abstract}
The primary purpose of the research is to develop new scientific approaches to the implementation of joint innovation and investment projects in the framework of cooperation between developing countries on the example of the Republic of Kazakhstan and the Russian Federation. The methodology of the study included the use of a system of methods: the analytical and induction methods, hypothesis and the synthesis method. As part of the analytical and induction methods, the general theory of investment projects implemented by business entities of two or more countries was investigated. When considering the theory of investment and innovation projects, the following aspects were studied: basic fundamental attributes of project implementation; modelling of investment and innovation projects; modelling of the development of cross-country investment and innovation projects with the participation of two or more countries; factors influencing the effectiveness of cross-country investment and innovation projects. The study focused on the impact of investment and innovation projects on the economic growth of developing countries. Based on the results obtained using the analytical method, the general problems of intensification of investment projects were developed. Based on the identified problems, the method of hypothesis formulation was applied, which allowed formulating postulates on the application of several new methods of integration and economic cooperation of the states. The findings of the research allow in developing a new economic policy of cooperation of developing and, in some aspects, developed countries and applying it in practice in the conditions of increasing global competition.
\end{abstract}

Keywords: Project, Investment, Innovation, Economic System, Globalisation, Economic Cooperation, Industry

\footnotetext{
† Plekhanov Russian University of Economics, Stremyanny Lane, 36, Moscow, 117997, Russia

${ }^{*}$ Corresponding Author, Email: saulesha_rahimova@mail.ru

(C) 2019 Rakhimova \& Goncharenko. This is an Open Access article distributed under the terms of the Creative Commons Attribution License (http://creativecommons.org/licenses/by/2.0), which permits unrestricted use, distribution, and reproduction in any medium, provided the original work is properly cited.
} 


\section{Introduction}

In the context of globalisation, most states choose the strategy of catching-up and advanced development. It is crucial for developing countries to ensure economic stability, maintain their positions in the domestic market, increase their competitive advantages and occupy a particular niche in the global market system (Competitiveness rating of the economies of the world 2017-2018). In this context, globalisation is considered as a set of the following trends:

- unification of economies of several countries;

- the emergence of large-scale crosscountry production and markets;

- dynamic growth in world trade;

- accelerating global scientific and technological progress and competition;

- formation of a single information space through the Internet and ITtechnologies.

Considering those above, it is important to identify priorities for the development of a country, to activate the existing potential and to implement investment projects that give a quantitative and qualitative effect at the micro, meso and macro levels.

Practice shows that the economic development of any state, the achievement of qualitative rates of economic growth is possible only on the basis of the development of real sectors of the economy, where the primary vector is focused on production processes and the creation of products with high added value, able to compete in the global market space. Taking into account the world trends of competition and scientific and technical progress, the transition to the fourth level of the scientific and technological revolution and the development of the production sector of the economy of a given state cannot be unipolar.

In production processes and implementation of investment and innovation projects, several participating countries must be involved, each of which fulfils its significant economic and organisational function. The latter should contribute to the accumulation of qualitative indicators of the economic system development of the countries participating in the implementation of projects, such as improving positioning in global competitiveness rankings, significant growth in the level of innovative activity of business and entrepreneurship, achieving and maintaining real GDP per capita, stabilising exchange rates and abolishing their negative influence on the economy.

It should be noted that most countries, including the Republic of Kazakhstan and the Russian Federation, have significant reserves of improvement in terms of the above indicators. This fact is directly and indirectly evidenced by the global competitiveness rating of the world and the positioning of these countries in it (Competitiveness rating of the economies of the world 2017-2018). Despite the long period of development and deepening of modern market relations, these countries have a pronounced range of problems in the field of competitiveness of production, the level of innovative activity, the quality of economic growth, the devaluation of national currencies and the growth of inflation processes (Economy of the Republic of Kazakhstan, Inflation, 2018).

Similar problems are inherent primarily in several other developing countries, the competitiveness rating of which can strive for better, higher positions (Competitiveness rating of the economies of the world 2017-2018). All other things being equal, the developed countries are facing similar problems, where the world's largest companies are becoming inefficient. As an example, one can mention the decline in the competitiveness of large companies in the prosperous countries of Finland and Sweden. A well-known fact is the destabilisation of the market and the decline in the competitiveness and efficiency of global companies - Nokia, Erickson (Flash chance for Nokia and Ericsson, 2018).

One of the options for overcoming and eliminating these problems can be the creation of new methods for building effective and 
functioning organisational and economic mechanisms for the participation of developed and developing countries in the implementation of joint investment and innovation projects. The implementation of investment and innovation projects determines the scientific search for proper solutions.

The general logical course (layout) of scientific thought aimed to achieve this goal, takes the following forms:

- study of theoretical foundations of investment and innovation projects (basic attributes of project implementation, modelling of investment and investment and innovation projects, modelling of implementation of joint cross-country investment and innovation projects);

- formulation of problem-target aspects of the implementation of investment and innovation projects in the framework of economic cooperation of the Republic of Kazakhstan and the Russian Federation and the impact of these problems on the dynamics of GDP);

- development and justification of economic factors affecting the implementation of joint investment and innovation projects in the framework of economic cooperation of the Republic of Kazakhstan and the Russian Federation, and ;

- systematisation and specification of new methods of implementation of investment and innovation projects (on the example of the Republic of Kazakhstan and the Russian Federation).

Taking into account the experience of the Republic of Kazakhstan and the Russian Federation, this research discusses new methods for the implementation of joint investment and innovation projects in both developed and developing countries. In the next section, we discuss the methodological aspects linked with the research.

\section{Methodology}

In modern theory and practice, the implementation of variational investment and innovation projects is one of the main engines of economic development of developed and developing countries.

The term "project" in economic systems is directly related to the management activities of businessmen, entrepreneurs, top managers of enterprises, firms, companies. A project is understood as a temporary enterprise aimed at creating a unique product, service or result (A Guide to the Project Management Body of Knowledge, 2013).

In world theory and practice, there are also a number of other alternative approaches to understanding the term "project" (Systems and software engineering - System life cycle processes; Systems and software engineering Measurement process; Information technology - Vocabulary - Part 20: System development; Systems and software engineering Requirements for designers and developers of user documentation; Projektmanagement Projektmanagementsysteme).

As studies show, the conceptual apparatus for the implementation of projects is regulated by international standards. The main scientific approaches to the definition of the term "project", allow identifying its basic fundamental attributes as presented in Figure 1.

Allocation and specification of the basic fundamental attributes of project implementation identify the two most important components - the need for projects in resources and the achievement of their specific uniqueness. The latter, in our opinion, indicates that in theory and practice, according to the qualitative criterion, two types of projects can be singled out:

- investment projects;

- investment and innovation projects. 


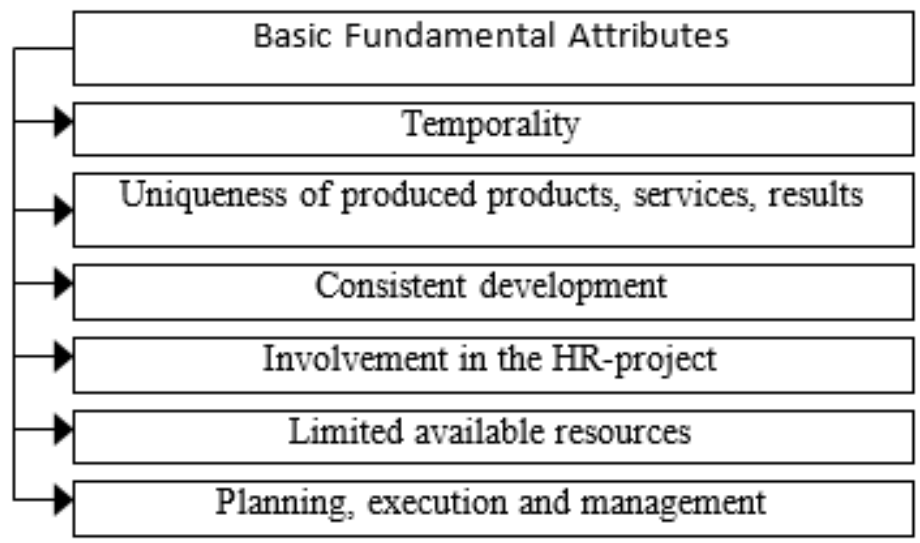

Figure 1: Basic Fundamental Attributes of Project Implementation Source: Compiled by the Authors

The implementation of any project involves the availability of investments and sources of their financing. Therefore, any project can be considered an investment (Gerasimenko, 2013; Heiskanen, 2014).

When modelling an investment project, investment is financed in such areas as:

main capital;

- working capital (circulating assets);

- training and retraining of HR resources in accordance with the goals and objectives of the projects being implemented (McConnell, Brue, Flynn, 2018).

In modern market conditions, taking into account the dynamically increasing competition, entrepreneurs and businessmen within the framework of implementing investment projects must achieve a certain level of product uniqueness and ensure the level of its innovativeness. To this end, along with the financing of earlier considered investments, it is necessary to finance investments in innovations in the following areas:

- research works (fundamental and applied);

- development work (research and development - R\&D).
Comparing investment and innovation processes, it is possible to design a model of an investment and innovation project, which is illustrated in Figure 2.

To ensure a high level of competitiveness and innovation, the implementation of investment projects should be associated with the use of high technology.

From the logical point of view, the innovation process, based on the development of high technology, is emphasised four components:

- high-tech idea;

- high-tech manufacturing process;

- high-tech products;

- high technologies of introduction to the market and bringing the goods to the end user (Martynenko, 2006).

The last decade has shown that the world market for high technologies is developing at a breakneck pace. The potential of both developed and developing countries do not always allow for the implementation of hightech investment and innovation projects. As a consequence, it is necessary to combine the investment and innovation potentials of two or more countries (Zakharova, Labudin, 2016). This fact stipulates a high level of relevance of the implementation in practice of mutual crosscountry investment and innovation projects. 


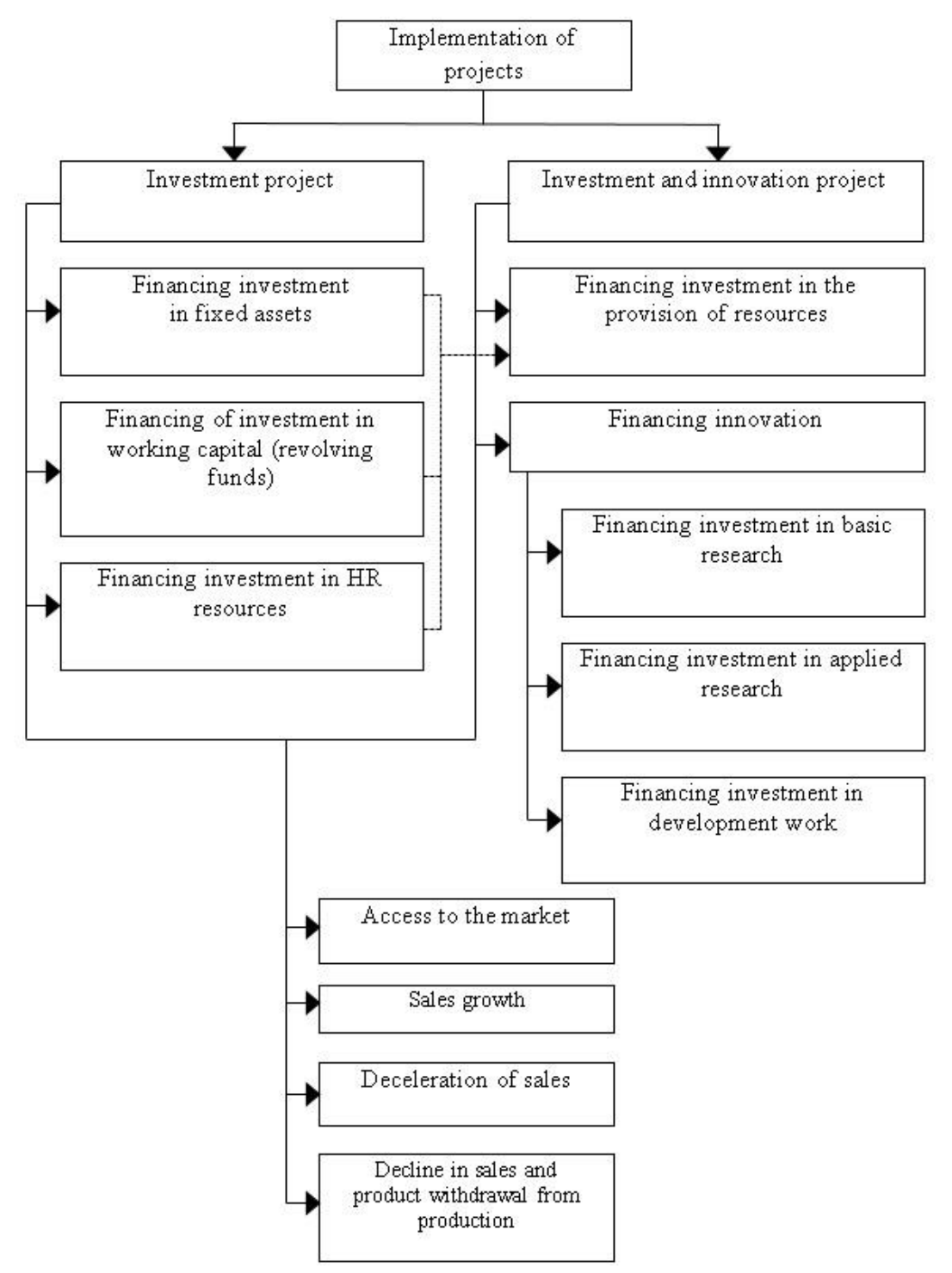

Figure 2: Modelling of Investment and Innovation Projects Source: Compiled by the Authors.

The implementation of joint investment and innovation projects within the framework of interaction between developed and developing countries suggests:

- integration of investment potential;

- integration of innovation potential;

- consideration of environmental factors.

In general, the simulation of the implementation of joint cross-country investment and innovation projects is demonstrated in Figure 3.

The implementation of joint investment and innovation projects within the framework of international economic cooperation should be oriented towards solving economic problems and the progressive development of economic systems.

For example, the implementation of joint investment and innovation projects in the system of economic cooperation of such countries as the Republic of Kazakhstan and the Russian Federation should involve solving a set of economic problems. In this connection, the following strategic-objective aspects can be formulated (Figure 4). 


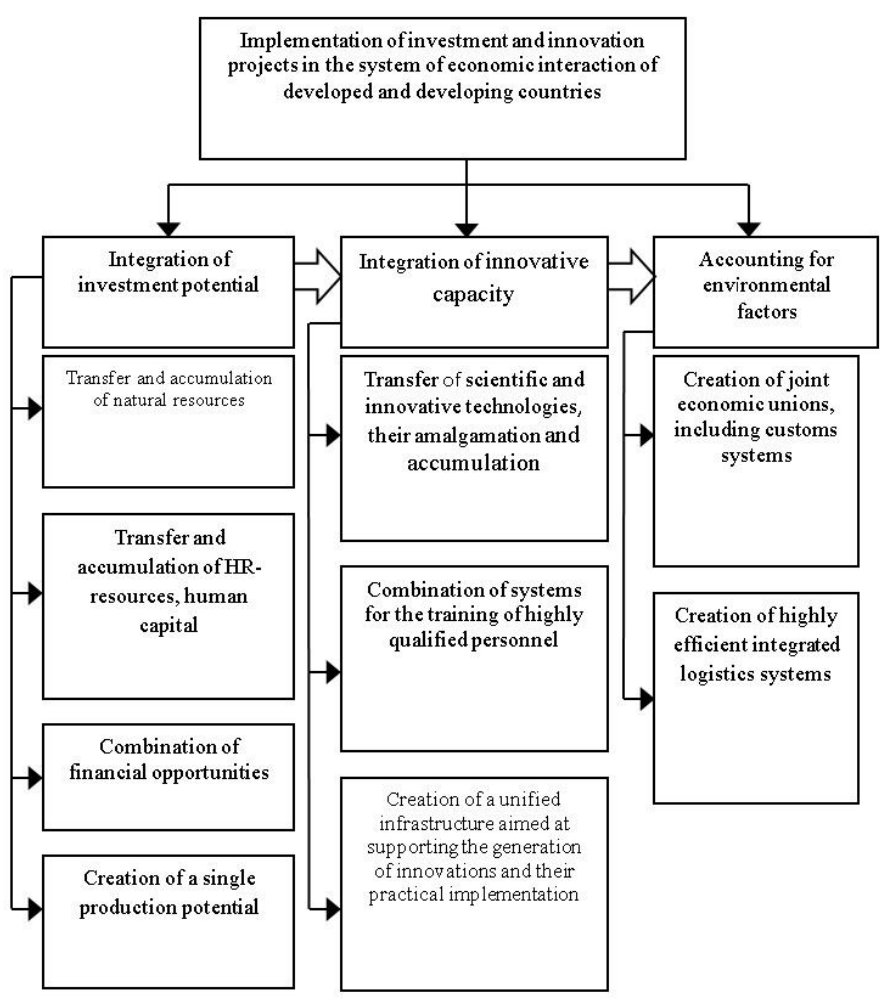

Figure 3: Modelling the Implementation of Joint Cross-Country Investment and Innovation

Projects.

Source: Compiled by the Authors.

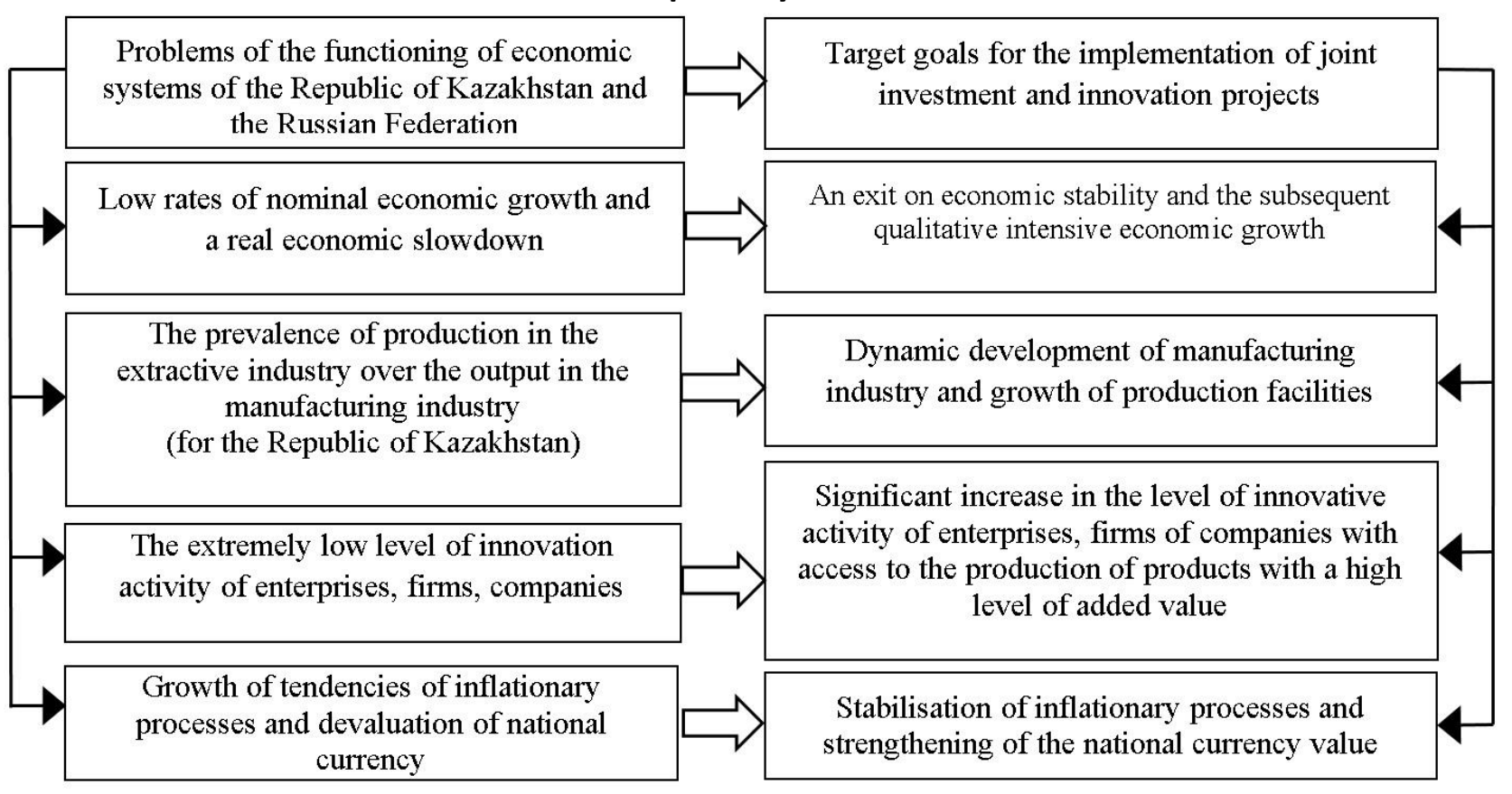

Figure 4: Problem-Specific Aspects of the Implementation of Investment and Innovation Projects in the Framework of Economic Cooperation between the Republic of Kazakhstan and the Russian Federation.

Source: Compiled by the Authors.

The initial economic problem of both the Republic of Kazakhstan and the Russian Federation is the real economic recession, the comparative dynamics of which are displayed in Table 1. 


\begin{tabular}{|c|c|c|c|c|c|}
\hline \multirow[t]{2}{*}{ Indicator } & \multicolumn{5}{|c|}{ Years } \\
\hline & 2012 & 2013 & 2014 & 2015 & 2016 \\
\hline $\begin{array}{l}\text { Real GDP of the Republic of Kazakhstan, billion } \\
\text { US dollars }\end{array}$ & 208.0 & 236.6 & 221.4 & 184.4 & 137.3 \\
\hline $\begin{array}{l}\text { Real rate of economic growth in the Republic } \\
\text { of Kazakhstan, \% }\end{array}$ & - & 13.8 & -6.4 & -16.7 & -25.5 \\
\hline $\begin{array}{l}\text { Real GDP of the Russian Federation, billion US } \\
\text { dollars }\end{array}$ & 2149.2 & 2208.2 & 2200.6 & 1330.7 & 1219.8 \\
\hline $\begin{array}{l}\text { Real rate of economic growth in the Russian } \\
\text { Federation, \% }\end{array}$ & - & 2.7 & -0.3 & -39.5 & -8.3 \\
\hline \multicolumn{6}{|c|}{$\begin{array}{l}\text { Source: Compiled by the Authors based on National Accounts of the Republic of Kazakhstan } \\
\text { in 2012-2016, 2018; Russia by the Numbers 2017, 2017; The Dynamics of the Dollar to the } \\
\text { Rouble for } 25 \text { years, 2016. }\end{array}$} \\
\hline
\end{tabular}

Another significant problem of the economic systems is the disparity in the volumes of production and development in the context of the extractive and manufacturing industries. Unlike the Russian Federation, this problem is peculiar to the Republic of Kazakhstan. In the total volume of industrial production in the Republic of Kazakhstan, the share of the manufacturing industry for the years of development of the market economy has reached $46.2 \%$, while the extractive industry continues to play the locomotive role in the functioning of the economic system. A similar indicator in the Russian Federation is $74.8 \%$ (Kazakhstan's industry and its regions in the period 2012-2016, 2017; Industrial production in Russia in 2016, 2016).

Analysis of the structure of industry shows that in Kazakhstan, at the present stage, the third and fourth technological structure is developing. The indicators that relate to the fifth technological order in the industry range from 0.4 to $3 \%$.

The Russian Federation is largely ahead of the Republic of Kazakhstan in the fourth and fifth technological order with production in the manufacturing industry three times higher.

Despite the fundamental differences in the development of the extractive and manufacturing industries, the general problem in the Republic of Kazakhstan and the Russian
Federation is the low level of innovative activity of enterprises (firms, companies) on the one hand and, on the other hand, the low share of $R \& D$ expenditures in GDP.

The level of innovative activity in the analysed countries within the strategic period did not exceed $10.5 \%$. At the same time, the shares of R\&D expenditures in GDP in the Republic of Kazakhstan and in the Russian Federation do not meet the efficiency criteria and amount $0.14 \%$ and $1.1 \%$ respectively (Science and innovative activity in Kazakhstan in 2012-2016, 2017; Science and Innovation in the Russian Federation, n. d.). World practice shows that the share of R\&D expenditures in GDP should be at least $4 \%$, which corresponds to the high-tech level of industry and the economy of a country (Zakharova, Labudin, 2016).

As a consequence, a low level of innovative activity and insufficient level of R\&D funding leads to a decrease in the competitiveness of national economies.

According to M. Porter, the competitiveness of a particular economic system depends on the ability of its industry to innovate and modernise (Porter, 2011).

In 2017-2018, Kazakhstan gained 57th place out of 137 countries in the global ranking of competitiveness, while the Russian Federation 
stood at 38th place (Competitiveness rating of the economies of the world 2017-2018).

In our opinion, the current economic situation both in the Republic of Kazakhstan and in the Russian Federation requires activation of the implementation of investment and innovation projects, while economic efforts and investment and innovation opportunities of the two countries can be combined. A similar situation in the global economy is typical for other states.

In order to implement joint investment and innovation projects, the Republic of Kazakhstan and the Russian Federation have all the significant economic factors presented in Figure 5.

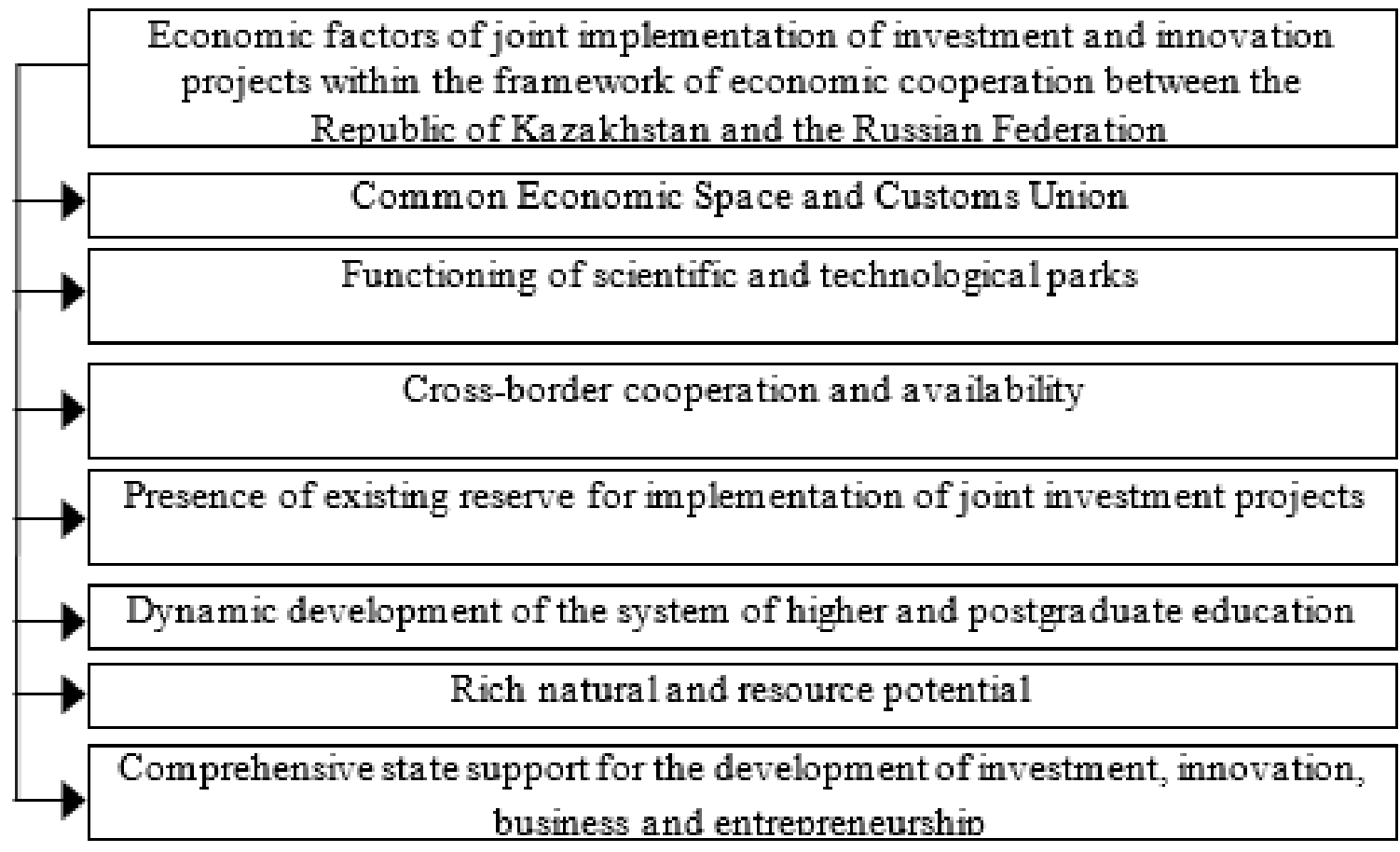

Figure 5: Economic Factors Affecting the Implementation of Joint Investment and Innovation Projects in the Framework of Economic Cooperation between the Republic of Kazakhstan and the Russian Federation.

Source: Compiled by the Authors.

Meanwhile, in the system of economic cooperation of the Republic of Kazakhstan and the Russian Federation, joint investment and innovation projects, including those focused on the development of high technologies and contributing to the growth of innovative activity and investments in R\&D, are only developing to a small extent.

\section{Results}

The results of the research and new scientific provisions on the formation of new methods for the implementation of joint investment and innovation projects based on the example of the countries under study are shown in Figure 6. 


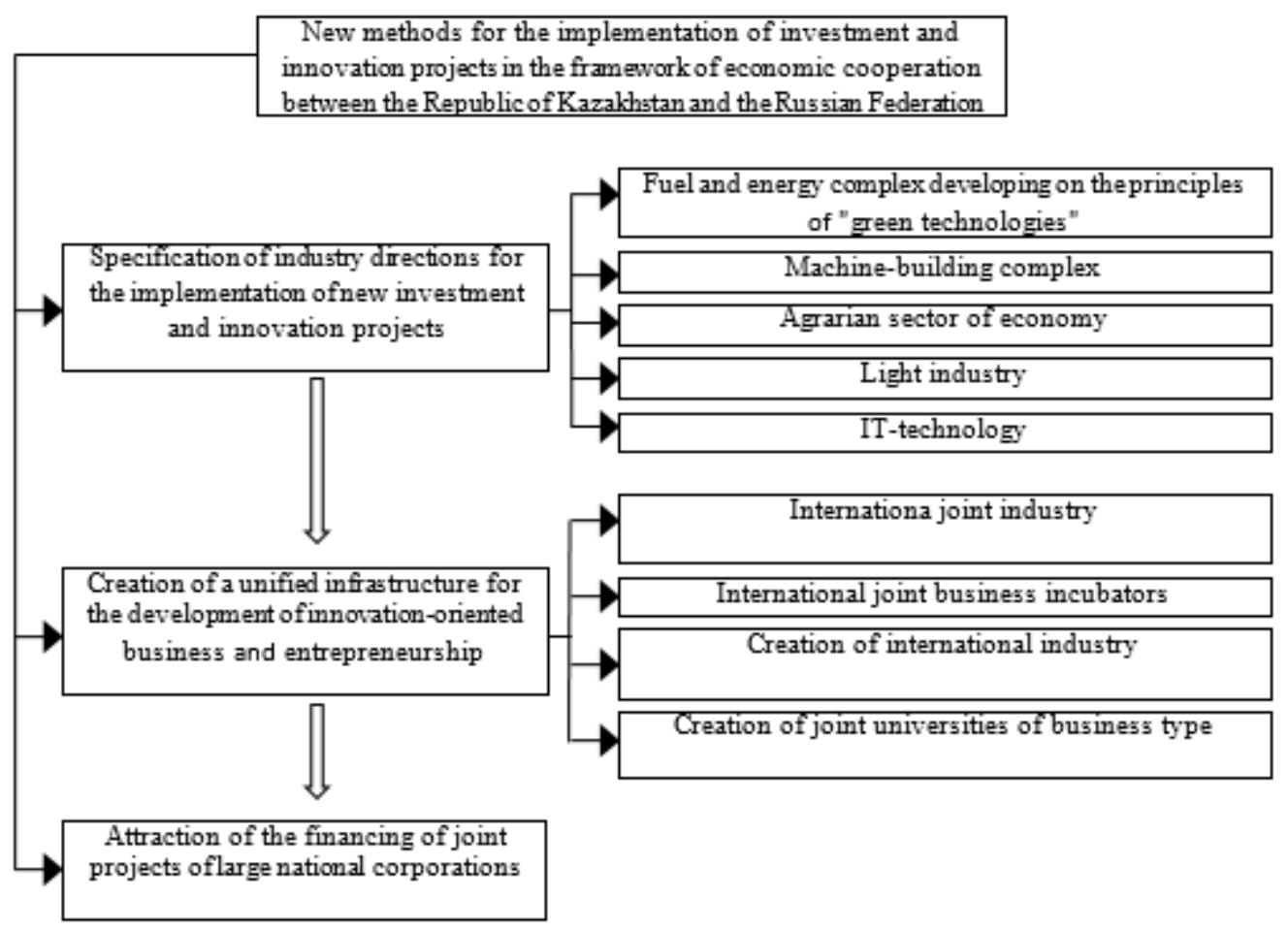

Figure 6: Systematisation and Concretisation of New Methods for the Implementation of Investment and Innovation Projects (on the example of the Republic of Kazakhstan and the Russian Federation). Source: Compiled by the Authors.

Joint investment and innovation projects should directly and positively, influence the trends of economic growth and the stabilisation of the economic system as a whole and ensure its competitiveness.

The following methods can serve for the implementation of investment and innovation projects within the framework of economic cooperation between the Republic of Kazakhstan and the Russian Federation (Figure 6):

- the concretisation of industry directions for the implementation of new investment and innovation projects;

- creation of a unified infrastructure for the development of business and entrepreneurship;

- attraction to the financing of joint projects of large national corporations.

The methods for the implementation of joint investment and innovation projects should be integrated into a system. In particular, at the first stage, it is necessary to clearly specify and identify sectoral areas for the implementation of projects.

At the second stage, the creation of a unified infrastructure for the development of business and entrepreneurship is implemented.

The third method is to attract investments. In this aspect, in our opinion, large national corporations with significant financial and economic potential should be involved in the implementation of investment and innovation projects.

\section{Discussion}

Currently, with the growth of integration processes in the world, the issue of cooperation is not only related, but have become important to connect to the remote economies. Economists discuss various examples of the economic integration of developed and developing countries to implement joint investment and innovation projects. For 
example, Russian economists A.Yu. Knobel and M. A. Baeva consider different models of economic and industrial integration and cooperation of countries in the European Union (Knobel, Baeva, 2013).

The issue of cross-country integration has found extensive scientific discussion on in terms of the advantages and disadvantages of the implementation of joint investment and innovation projects, as well as the production and economic integration of individual enterprises.

One of the discussed issues is the observance of democratic freedoms and human rights in the implementation of joint international projects. At the same time, economists have introduced the term "compulsory economic integration" (Dalimov, 2009; Jovanovich, 1998).

In the world of the scientific community, the questions of the practical application of organisationally economic instruments of the scientific collaboration of the countries come into question as a separate aspect.

\section{Conclusion}

The current research aimed to discuss new methods for the implementation of joint investment and innovation projects in both developed and developing countries using the experience of the Republic of Kazakhstan and the Russian Federation. As the research has shown, the solution to the economic problems of both the developed and developing countries, it should be implemented based on the principles of integration and close investment, innovation and production cooperation. The leading target vector in this matter should be the implementation of a wide range of investment projects directly oriented to the dynamic development of innovation and new technologies.

Within the framework of this ongoing research, practical measures will be taken shortly to establish scientific and partnership links between technology parks, business incubators and universities of the Republic of Kazakhstan and the Russian Federation to discuss and create a pool of joint investment and innovation projects.

\section{References}

A Guide to the Project Management Body of Knowledge. (2013). Project Management Institute, Inc., Fifth Edition.

http://dinus.ac.id/repository/docs/ajar/PMBOK Guide_5th_Ed.pdf.

Competitiveness rating of the economies of the world 2017-2018. Financial Daily eXpress. http://fdlx.com/politic/mir/100985-rejtingkonkurentosposobnosti-ekonomik-stran-mira2017-2018.html.

Dalimov, R.T. (2009). The dynamics of the trade creation and diversion effects under international economic integration. Current Research Journal of Economic Theory, 1(1).

Dinamika kursa dollara k rublyu za 25 let: Infografika. [The dynamics of the dollar to the rouble for 25 years: Infographics]. (2016). http://www.aif.ru/dontknows/infographics/din amika_kursa_dollara_k_rublyu_za_25_let_infog rafika.

Economy of The Republic of Kazakhstan. Inflation. (2018) Electronic resource: https://economy.gov.kz/ru/news/inflyaciya-vrespublike-kazahstan-v-2018-godu-sostavila-53

Flash chance for Nokia and Ericsson. (2018)

Electronic resource:

http://finfront.ru/2018/04/20/a-happy-chancefor-nokia-and-ericsson/.

Gerasimenko, A. (2013). Finansovyy menedzhment - eto prosto: Bazovyy kurs dlya rukovoditeley i nachinayushchikh spetsialistov. Moscow: Alpina Publisher, 532.

Heiskanen, I. (2014). Design Process in Investment Projects. Helsinki Metropolia University of Applied Sciences. http://www.theseus.fi/bitstream/handle/10024 /76216/Ilkka-Heiskanen-IM-20132014.pdf;jsessionid=E4E01B9C72A44CEFCA971 CBOD5832035 ?sequence $=1$.

Information technology - Vocabulary - Part 20: System development. ISO/IEC 2382-20:1990. 
International Organisation for Standardization. https://www.iso.org/standard/7264.html.

Jovanovich, M. (1998). International Economic Integration. Limits and Prospects. Routledge: Second edition, 472 .

Knobel, A.Yu., Baeva, M.A. (2013). World experience of trade and economic cooperation of large integration associations and geographically remote economies. Evrasiyskaya Ekonomicheskaya integratsiya, 2(19): 7-20.

Martynenko, A.V. (2006). Vysokiye tekhnologii i vyssheye obrazovaniye. Znaniye. Ponimaniye. Umeniye, 1, 64-67.

McConnell, C.R., Brue, S.L., Flynn, S.M. (2018). Economics: Principles, Problems, and Policies. 19th Edition. ISBN-10: 0073511447.

Natsional'nyye scheta Respubliki Kazakhstan v 2012-2016 gody: Statisticheskiy sbornik [National Accounts of the Republic of Kazakhstan in 2012-2016: statistical yearbook]. (2018). Astana.

Nauka i innovatsii v Rossiyskoy Federatsii. Federal State Statistics Service. [Science and Innovation in the Russian Federation] http://www.gks.ru/wps/wcm/connect/rosstat main/rosstat/ru/statistics/science_and_innovat ions/science/.

Nauka i innovatsionnaya deyatel'nost' Kazakhstana v 2012-2016 gody [Science and innovative activity in Kazakhstan in 2012-2016]. (2017). Astana.

Porterm, M.E. (1991). Towards a Dynamic Theory of Strategy. Strategic Management Journal, 12(Winter Special Issue), 95-117.

Projektmanagement -

Projektmanagementsysteme. DIN 69901.

Projekt Magazin.

https://www.projektmagazin.de/glossarterm/di n-69901-projektmanagement-

projektmanagementsysteme.

Promyshlennost Kazakhstana i yego regionov v 2012-2016 gody [Kazakhstan's industry and its regions in the period 2012-2016]. (2017).

Astana.

Promyshlennoye proizvodstvo v Rossii v 2016: Statisticheskiy sbornik. [Industrial production in Russia in 2016: Statistical Yearbook]. (2016). Moscow: Rosstat, 347.

Research and Development - R\&D. (2017). Investopedia.

https://www.investopedia.com/terms/r/randd. asp.

Rossiya v tsifrakh 2017: Kratkiy statisticheskiy sbornik [Russia by the Numbers 2017: Short Statistical Book]. (2017). Moscow: Rosstat, 511.

Systems and software engineering Measurement process. ISO/IEC 15939:2007. International Organisation for Standardization. https://www.iso.org/standard/44344.html.

Systems and software engineering Requirements for designers and developers of user documentation. ISO/IEC 26514:2008. International Organisation for Standardization. https://www.iso.org/standard/43073.html.

Systems and software engineering - System life cycle processes. ISO/IEC 15288:2008.

International Organisation for Standardization. https://www.iso.org/standard/43564.html.

Zakharova, N.V., Labudin, A.V. (2016). Mirovoj rynok vysokikh tekhnologij: osobennosti i perspektivy razvitiya [World market of high technologies: features and development prospects]. Nauchnyy zhurnal: Vlast' i ekonomika, 4: 103-115.

\section{Acknowledgements}

The present research was prepared in the framework of the study at the Department of Economics of the Pavlodar State University named after S. Toraigyrov (Republic of Kazakhstan). The authors express their gratitude to the teaching staff of the department and the scientific advisors who supervise the issues of fundamental and applied research. 